\title{
Amenities and Fringe Benefits:
}

\section{Omitted Variable Bias}

\author{
By Philip E. Graves, Robert L. Sexton, and Michelle M. Arthur*
}

ABSTRACT. If labor is fairly mobile, as it is in the United States, one would expect that households would move from less desirable areas toward more desirable areas until all areas are equally desirable. The way that areas become equally desirable is through the impact of movers on wages and rents (and possibly "endogenous" disamenities, such as congestion or pollution). That is, as people move to desirable areas, they will increase the demand for land (raising rents) and increase the supply of labor (lowering wages); in equilibrium, the wage and rent "compensation" for the niceness of an area reveals, in dollar terms, just how nice the area is. Blomquist, Berger, and Hoehn 1988 demonstrated the empirical importance of such amenity compensation in estimates of the "quality-of-life" in urban areas. However, those authors were unable to include fringe benefits, which are about 40 percent of explicit wage payments, in their wage compensation. This matters greatly as amenities are seen here to be even more important than previously thought and the regional implications are pronounced, with the West and Southeast looking "better" when fringe benefits are included and the East North Central and Northeast looking substantially "worse."

* Professor Philip E. Graves teaches economics at the University of Colorado, Boulder, C0 80302. Email: gravesp@spot.colorado.edu. Professor Graves' research interests include the role of amenities in human location and relocation, hedonic valuation, and miscellaneous applied microeconomic topics. He is the author of six books and more than fifty referred journal articles. Professor Robert L. Sexton is Distinguished Professor of Economics at Seaver College and the School of Public Policy at Pepperdine University, Malibu, CA 90263. Email: rsexton@pepperdine.edu. Professor Sexton's research interests include statute and enforcement costs, migration, and regional economic growth and development. He is the author of Exploring Economics (Harcourt College Publishers, www.Dryden.com). Michelle Arthur is a graduate student in the Institute of Labor and Industrial Relations Department, University of Illinois, 504 East Armory, Champaign, IL 61820. Email: martbur@students.uiuc.edu. Ms. Arthur's interests include gender wage differentials.

American Journal of Economics and Sociology, Vol. 58, No. 3 (July, 1999).

(C) 1999 American Journal of Economics and Sociology, Inc. 


\section{Introduction}

IN A GROUNDBREAKING empirical test of ideas advanced by Roback 1982 and Rosen 1979, Blomquist, Berger, and Hoehn 1988 demonstrated that amenities are highly valued by people and that those values are expressed in both land and labor markets. Sketching the argument, one would expect that people would move to initially desirable locations until some mix of lower wages (as the supply of labor increases) and higher rents (as the demand for land increases) offsets the locations' desirability. Indeed, in this manner one can gauge the "quality-of-life" of various locations by adding up what is paid in land and labor markets (the Blomquist, Berger, and Hoehn contribution). Graves and Waldman 1991 show that this equilibrium model is consistent with the observed migration behavior of the elderly retired (that is, one observes retirees moving to areas where more of the compensation for amenities occurs in labor markets that are no longer relevant). The economics literature in this area contrasts markedly with the work of geographers (e.g. the many Rand-McNally "Places Rated Almanacs," that arbitrarily give equal weight to various traits that are valued on a subjective one-to-five scale). The economics approach described here uses peoples' observed willingness-to-pay for various amenities, hence should, we think, be greatly preferred.

In this paper, we extend this literature to the consideration of fringe benefits. The notion is that it is full wage compensation that will be lowered in desirable locations relative to elsewhere, ceteris paribus, and that full compensation is comprised of a mix of explicit wage payments and a fringe package. This would not matter if there were a "standard" fringe package that did not vary across locations, but we shall see that fringes vary greatly over space, and in the expected direction-nice locations offer inferior fringes in addition to lower hourly wages. The wage portion of the full compensation (lower wages and higher rents in nice locations) should be comprised of the impacts on both wages and fringe payments.

Total employee benefits nationwide have grown from 18.7 percent of payroll in 1951 to 38.4 percent in 1990. The adjustment of wage compensation to incorporate fringe benefits will be seen to be a non-trivial adjustment: amenities are substantially more important than previously thought and the regional implications are pronounced. 
Section II discusses procedures necessary for incorporation of the effects of variation in fringe benefits on amenity valuation. In this section strong empirical effects are seen despite significant data limitations. Section III concludes with some broader implications of the paper.

II

\section{Analysis}

TABLE 1 PRESENTS the regional data that underlie the paper (unfortunately employee benefits are unavailable at either the county or state level). Columns (1) and (2), however, aggregate to the regional level the county-level 1980 information on wage and rent compensation of Blomquist, Berger, and Hoehn 1988 (we wish to thank Glenn Blomquist for providing us with this county level information). The regional population-weighted averages for the U.S. are then calculated and used to create a relative wage and rent compensation number in Columns (4) and (5). For example, West's raw wage compensation of $\$ 469.98$ is $\$ 283.70$ below the national average compensation of $\$ 753.68$ in the data; similarly rent compensation in the West is $\$ 583.60$ higher than the U.S. average. Adding the negative wage compensation to the positive rent compensation results in an overall amenity payment for the West of $\$ 299.90$, ignoring employee fringe benefits, as seen in Column (7). The raw employee benefits for the same period, seen in Column (3), are calculated from information on total employee benefits as a percent of payroll multiplied by average payroll per employee, by region. Again considering the West, payroll per employee in 1980 was $\$ 12,795$ and $35.2 \%$ of that is received as fringe benefits in the West, yielding fringe benefits of $\$ 4,503.84$. For purposes of comparison, the numbers underlying the Northeast were $\$ 13,297$ and $38.1 \%$, resulting in total fringe benefits per employee of $\$ 5,066.16$. Again, normalizing on the U.S. average, the relative fringe compensation in the West is seen in Column (6) to be $\$ 105.14$ - that is, the amenity privilege of living in the West of $\$ 299.90$ comes with an additional payment in the form of lower than U.S. average ( $\$ 4608.98$ ) fringe benefits.

Comparing Columns (7) and (8) we can see the pronounced impact of employee fringe benefits on the relative value of amenities among regions. Considering Column (7) which ignores benefits, it would appear that the West is only slightly better than average, the Southeast is a bit worse than 


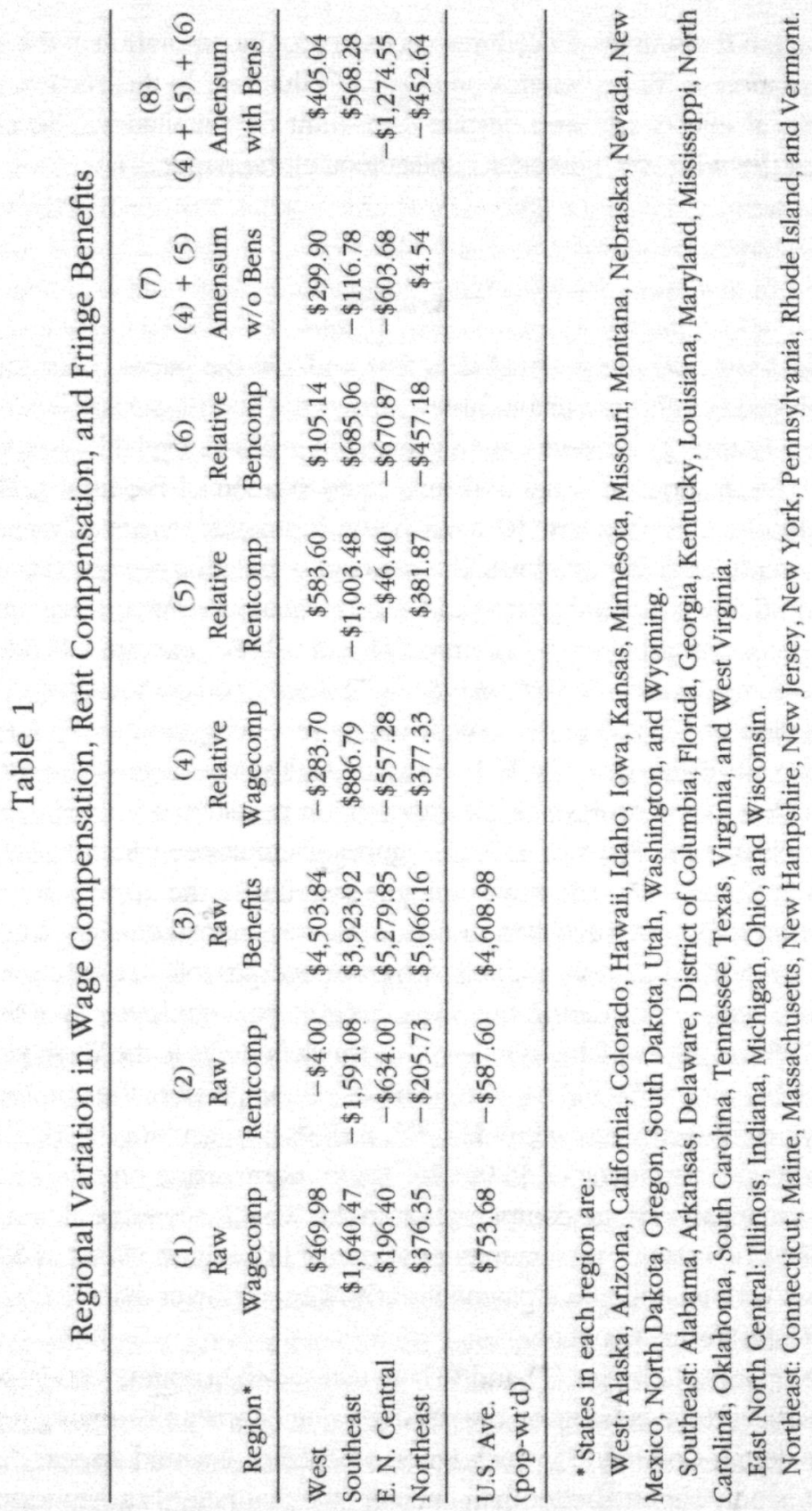


average, the East North Central is somewhat below average, and the Northeast is about average. For people that have traveled or lived for significant periods in these regions, the corrected numbers in Column (8) are likely to seem much more plausible. The West and Southeast are seen as possessing substantially above average amenity levels, while the Northeast is somewhat below average and the East North Central possesses substantially below average amenities.

Taking the view expressed elsewhere (see Graves 1979) that desirable amenities are also normal or superior goods (hence one would expect movement to nicer areas over time as incomes grow), one can see that Column (8) is more consistent with migration patterns observed in recent decades. Column (7) would lead one to expect movement toward the West and perhaps Northeast and away from the Southeast and the East North Central. But Column (8) provides more consistent support for the observation of large flows from the Rustbelt to the Sunbelt. The results also provide added support for the position of Mueser and Graves 1995 that regional growth and decline is more importantly driven by growth in amenity demands (supply-side) than by growth in demands for workers (demand-side).

III

\section{Conclusion}

THE CENTRAL finding here is that amenities, increasingly seen as having notable implications for urban, regional, and labor economics, are even more important that previously thought. The differences across regions are seen to be much larger (a gap from "best" to "worst" region of $\$ 1,842.83$ when considering employee benefits versus a gap of only $\$ 903.58$ when spatial variation in fringe benefits is ignored)

Additionally, we show that regional effects of amenities are more pronounced and more intuitively plausible than suggested by prior work. The West and Southeast are seen to both be much more highly desired for their amenities than are the Northeast and, particularly, the Midwest (East North Central).

It is becoming increasingly apparent that amenities have an important impact on the answers to a host of long-standing questions in labor economics. That a substantial component of wage compensation for amenities 
comes via fringe benefits further augments these findings. The preceding insights were obtained despite remarkably poor spatial detail in the data. We believe that substantial gains in knowledge would result from obtaining information on fringe benefits at a finer geographical level.

\section{References}

Blomquist, Glenn C., Mark C. Berger, and John P. Hoehn. 1988. "New Estimates of Quality of Life in Urban Areas," American Economic Review, 78, 89-107.

Graves, Philip E. 1979. "A Life-Cycle Empirical Analysis of Migration and Climate, by Race," Joumal of Urban Economics, 6, 135-147.

Graves, Philip E. and Donald M. Waldman. 1991. "Multimarket amenity compensation and the Behavior of the Elderly," American Economic Review, 81, 1374-81.

Mueser, Peter and Philip E. Graves. 1995. "Examining the Role of Economic Opportunity and Amenities in Explaining Population Redistribution," Journal of Urban Economics, 37, 1-25.

Roback, Jennifer. 1982. "Wages, Rents and the Quality of Life," Journal of Political Economy, 90, 1257-1278.

Rosen, Sherwin. 1979. "Wage-based Indexes of Urban Quality of Life," in Current Issues in Urban Economics, P. Mieszkowski and M. Straszheim (eds). Baltimore: Johns Hopkins University Press. 
Copyright of American Journal of Economics \& Sociology is the property of Blackwell Publishing Limited and its content may not be copied or emailed to multiple sites or posted to a listserv without the copyright holder's express written permission. However, users may print, download, or email articles for individual use. 